\title{
LETTER
}

\section{The importance of diagnostic testing in the management of community-acquired respiratory infection during influenza season}

\author{
Tom W L Holmes', Andrew Campbell', Jaisi Sinha ${ }^{2}$ and Matt P Wise ${ }^{* 1}$ \\ See related research by Kuster et al., http://ccforum.com/content/15/4/R182
}

In a recent issue of Critical Care, Kuster and colleagues [1] reported an observational study of patients admitted to critical care during periods of high influenza activity. A diagnosis of respiratory infection and being febrile $\left(>38^{\circ} \mathrm{C}\right)$ were predictive of influenza among 126 confirmed subjects and had a higher predictive value for pandemic 2009 influenza A H1N1 (pH1N1) than seasonal influenza. A previous study identified that obesity, pregnancy, asthma, cardiac disease, immunosuppression, and diabetes are all risk factors for pH1N1 [2]. Such findings are important for focusing early optimal empiric therapy in addition to infection control measures during peaks of influenza activity. Nevertheless, it is important to investigate alternative differential diagnoses and pursue a definitive microbiological diagnosis when possible, particularly as bacterial co-infection occurs in almost a fifth of pH1N1 respiratory infections [3].

During the first 3 weeks of the 2010/2011 influenza season, 17 patients were admitted with proven influenza infection to critical care in our institution. A 28-year-old previously fit man presented at the end of this period with a 5-day history of dyspnea and cough. The patient was orientated, febrile $\left(38^{\circ} \mathrm{C}\right)$, hypoxic with an arterial oxygen saturation $\left(\mathrm{SaO}_{2}\right)$ of $88 \%$ to $90 \%$ on high-flow oxygen, and tachypnoeic. He was intubated within 3 hours of hospital admission for severe hypoxic respiratory failure. His leukocyte count was $12 \times 10^{9} / \mathrm{L}$, and his C-reactive protein level was elevated $(355 \mathrm{mg} / \mathrm{L})$. A chest radiograph on admission demonstrated four quadrant infiltrates (Figure 1). Microbiological samples included a throat swab and non-directed bronchoalveolar lavage (NBL) for respiratory viruses and blood for serology. Guideline-concordant antibiotics for community-acquired

*Correspondence: mattwise@doctors.org.uk

'Adult Critical Care, University Hospital of Wales, Heath Park, Cardiff, CF14 4XW, UK Full list of author information is available at the end of the article pneumonia (co-amoxiclav and clarithromycin) were initiated [4]. Oseltamivir was also administered as the clinical presentation was typical of critically ill patients admitted in the previous 3 weeks with confirmed influenza.

The NBL and throat swab did not confirm influenza by reverse transcription-polymerase chain reaction. In the context of the 2010/2011 influenza season and the high index of clinical suspicion, it was assumed that these results represented a false negative [5] and oseltamivir was continued for 10 days. The patient required mechanical ventilation for 5 days. All other antimicrobials were discontinued after 7 days as the patient had improved, and he was discharged home on day 9. Subsequently, serology for influenza became available and was negative but did confirm a diagnosis of Mycoplasma pneumoniae infection, for which the patient had received appropriate therapy.

Pattern recognition of symptoms and signs is a fundamental aspect of how clinicians formulate a diagnosis.

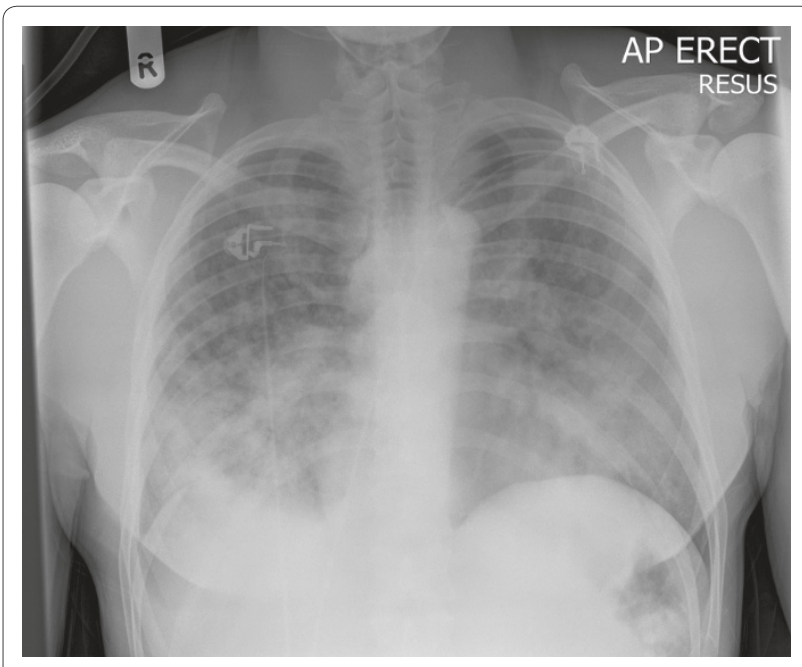

Figure 1. Chest radiograph on admission shows four quadrant infiltrates. AP, anteroposterior. 
Identifying features associated with a disease entity is an important aspect of improving this process but requires support from appropriate diagnostic tests that confirm or refute a diagnosis. The case described appeared typical of influenza infection during a period of intense influenza activity, but the serological results for Mycoplasma illustrate the importance of confirmatory diagnostic testing.

\section{Authors' response}

Stefan P Kuster and Allison McGeer

We thank Holmes and colleagues for their interest in our article. We agree that the consideration of various differential diagnoses is a critical priority for clinicians, particularly those working in intensive care units (ICUs). As the case of Holmes and colleagues demonstrates, there is good evidence that 'no specific symptom or combination of symptoms is diagnostic of [influenza]' [6]; in addition, a significant proportion of community-acquired pneumonia episodes requiring ICU care are polymicrobial [7].
The aim of our study was not to find symptom complexes that were diagnostic of influenza - a quixotic quest - but rather to identify populations in whom the probability of influenza was high enough that influenza testing, empiric antiviral therapy, or empiric infection control precautions (or a combination of these measures) was warranted [1]. The results of our study are intended to sensitize clinicians to ordering influenza testing in addition to not instead of - other diagnostic procedures.

\section{Abbreviations}

ICU, intensive care unit; NBL, non-directed bronchoalveolar lavage; $\mathrm{pH} 1 \mathrm{~N} 1$, pandemic 2009 influenza A H1N1.

\section{Competing interests}

The authors declare that they have no competing interests.

Acknowledgements

Written consent to publish was received from the patient.

\section{Author details}

'Adult Critical Care, University Hospital of Wales, Heath Park, Cardiff, CF14 4XW, UK. ${ }^{2}$ Public Health Wales Microbiology, University Hospital of Wales, Heath Park, Cardiff, CF14 4XW, UK.

Published: 9 January 2012

\section{References}

1. Kuster S, Katz K, Blair J, Downey J, Drews S, Finkelstein S, Fowler R, Green K, Gubbay J, Hassan K, Lapinsky S, Mazzulli T, McRitchie D, Pataki J, Plevneshi A, Powis J, Rose D, Sarabia A, Simone C, Simor A, McGeer A: When should a diagnosis of influenza be considered in adults requiring intensive care unit admission? Results from population-based active surveillance in Toronto. Crit Care 2011, 15:R182.

2. Kumar A, Zarychanski R, Pinto R, Cook D, Marshall J, Lacroix J, Stelfox T, Bagshaw S, Choong K, Lamontagne F, Turgeon AF, Lapinsky S, Ahern SP, Smith $O$, Siddiqui F, Jouvet P, Khwaja K, McIntyre L, Menon K, Hutchinson J, Hornstein D, Joffe A, Lauzier F, Singh J, Karachi T, Wiebe K, Olafson K, Ramsey C, Sharma S, Dodek P, Meade M, Hall R, Fowler RA; Canadian Critical Care Trials
Group H1N1 Collaborative: Critically ill patients with 2009 influenza A(H1N1) infection in Canada. JAMA 2009, 302:1872-1879.

3. Martín-Loeches I, Sanchez-Corral A, Diaz E, Granada RM, Zaragoza R, Villavicencio C, Albaya A, Cerdá E, Catalán RM, Luque P, Paredes A, Navarrete I, Rello J, Rodríguez A; H1N1 SEMICYUC Working Group: Community-acquired respiratory coinfection in critically ill patients with pandemic 2009 influenza A(H1N1) virus. Chest 2011, 139:555-562.

4. Lim WS, Baudouin SV, George RC, Hill AT, Jamieson C, Le Jeune I, Macfarlane JT, Read RC, Roberts HJ, Levy ML, Wani M, Woodhead MA: Pneumonia Guidelines Committee of the BTS Standards of Care Committee. BTS guidelines for the management of community acquired pneumonia in adults: update 2009. Thorax 2009, 64 Suppl 3:iii1-55.

5. Rello J, Rodríguez A, Ibañez P, Socias L, Cebrian J, Marques A, Guerrero J, Ruiz-Santana S, Marquez E, Del Nogal-Saez F, Alvarez-Lerma F, Martínez S, Ferrer M, Avellanas M, Granada R, Maraví-Poma E, Albert P, Sierra R, Vidaur L, Ortiz P, Prieto del Portillo I, Galván B, León-Gil C; H1N1 SEMICYUC Working Group: Intensive care adult patients with severe respiratory failure caused by influenza A (H1N1)v in Spain. Crit Care 2009, 13:R148.

6. Call SA, Vollenweider MA, Hornung CA, Simel DL, McKinney WP: Does this patient have influenza? JAMA 2005, 293:987.

7. Cilloniz C, Ewig S, Ferrer M, Polverino E, Gabarrus A, Puig de la Bellacasa J, Mensa J, Torres A: Community acquired polymicrobial pneumonia in the intensive care unit: aetiology and prognosis. Crit Care 2011, 15:R209.

\section{doi:10.1186/cc10494}

Cite this article as: Holmes TWL, et al:: The importance of diagnostic testing in the management of community-acquired respiratory infection during influenza season. Critical Care 2012, 16:401. 